UDC 811.111'42

DOI https://doi.org/10.32838/2710-4656/2021.4-1/13

Baybakova I. M.

Lviv Polytechnic National University

Hasko O. L.

Lviv Polytechnic National University

\title{
THEORETICAL AND EMPIRICAL ISSUES OF NEUROLINGUISTICS IN THE CONTEXT OF ESP STUDIES
}

Theoretical and empirical studies dealing with neurolinguistics have developed dramatically recently. Being of interdisciplinary character they may be taken advantage of by students majoring in medicine, philology, programming, AI, Machine Learning, etc.

Neurolinguistics concerns mind, brain, and language functioning which deals with the wide range of issues such as language areas in the brain, aspects of linguistic competence, real-time processing, neural networks, speech perception and auditory processing, the problem of speech recognition, lexical semantics, lexical and syntactic ambiguity, the neural architecture of language, etc.

There can be distinguished three main types of speech errors, namely: (1) the tip of the tongue phenomenon; (2) slips of the tongue; (3) slips of the ear. The algorithm of their understanding may provide possible clues to how our linguistics knowledge is organised within the brain.

The article is focused on the analysis of the latest advancements in the field of neurolinguistics, the basics of which can be incorporated into the curriculum of ESP courses related to applied linguistics, psychology, computer science, etc.

The present article provided insight into the relationship between language and the brain. There is no doubt that particular brain parts are responsible for many speech mistakes, misunderstandings and handicaps. The language centre located in the left hemisphere has a huge impact on the language abilities of every human being. The phenomenon of the brain structure is the basis for neurolinguistics research.

The latest findings reflect the language-brain relationship as well as the corresponding hypotheses about the neural representation and processing in terms of spoken/printed word forms, word meanings, and sentences. Advanced developments in the field of neurolinguistics enable fruitful multidisciplinary collaboration of researchers with different backgrounds referring to applied linguistics, psychology, computer science, etc. the results of which can be incorporated into the curriculum of the related ESP courses.

Key words: neurolinguistics, interdisciplinary field of studies, language - brain relationship, curriculum, ESP courses.

Stating the problem. Theoretical and empirical studies dealing with neurolinguistics have developed dramatically recently. Some of their peculiar aspects may be taken advantage of by students majoring in medicine, philology, programming, AI, Machine Learning, etc.

Stating the task. The article is focused on the analysis of the latest advancements in the field of neurolinguistics the basics of which can be incorporated into the curriculum of ESP courses related to applied linguistics, psychology, computer science, etc.

Analysis of the research and publications on the issue under consideration. The book "The Routledge Handbook of Linguistics" edited by Keith Allan contains the chapter "Neurolinguistics: Mind, brain, and language" which reads that neurolinguistics as the interdisciplinary field of research deals in particular with some fundamentals of the neural architecture of language such as "left-hemisphere dominance and the strong reliance of speech perception and production on certain regions in the temporal and frontal lobes" [6, p. 1]. According to the author, David Kemmerer, Ph. D. (Purdue University, Department of Speech, Language, and Hearing Sciences; Department of Psychological Sciences) the goal of neurolinguistics is "to understand how the cognitive capacity for language is subserved by the biological tissue of the brain" $[6$, p. 1$]$.

John C. L. Ingram (University of Queensland, Australia), the author of the book "Neurolinguistics: An Introduction to Spoken Language Processing 
and its Disorders", dwells on co-evolution of language and the brain, language areas in the brain, aspects of linguistic competence, minimal design features of a language, phonology, time reference: tense, aspect and modality, real-time processing, connectionist models and neural networks, speech perception and auditory processing, the problem of speech recognition, lexical semantics, word to sentence meanings, evaluation of symbolic models of lexical semantics, strategies for processing complex sentences, lexical and syntactic ambiguity for theories of language processing, working memory and modularity, individual differences in working memory capacity and sentence processing, discourse: language comprehension in context, discourse processing / modelling / construction, refining a model of discourse, breakdown of discourse, etc. [5].

The main body. Rapid development of neurolinguistics is caused by a variety of reasons, including "the maturation of modern linguistics, the cognitive revolution in psychology, the emergence of computer science and artificial intelligence, and the invention and progressive refinement of numerous brain mapping methods" [6, p. 1].

The following picture $[8$, p. 45-46] shows four main parts of the brain which are responsible for speaking and understanding the language. Without correlation between them the production of language and its understanding is impossible. Each has a different function and plays a different role in the language centre.

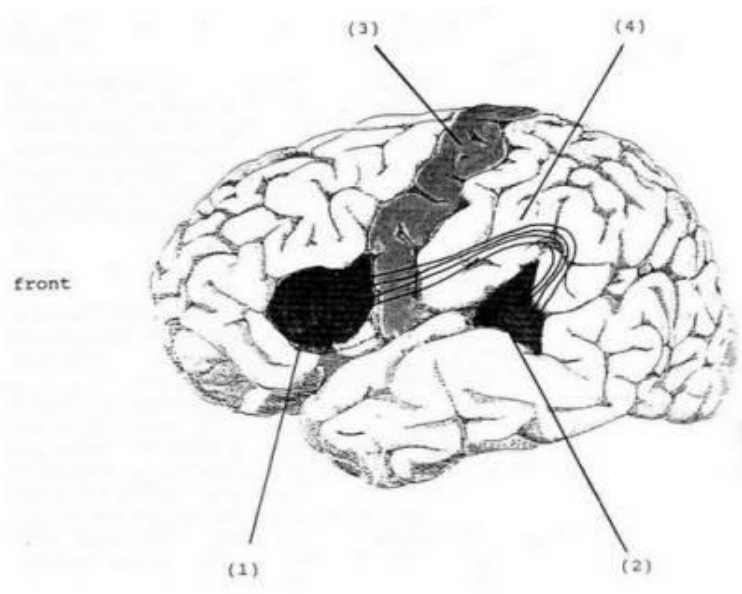

The part marked as (1) is Broca's area or "anterior speech cortex" and as it has been discovered it is responsible for speech production. Interestingly, damage made to the same spot on the right hemisphere of the brain does not cause any languagerelated problems, therefore only the part of the left hemisphere is connected with linguistic abilities.
"Posterior speech cortex", or as it is usually described Wernicke's area, in the picture marked (2) is responsible for speech comprehension. This fact has been found out after the examination of a group of subjects who had enormous difficulties with the understanding of speech.

The largest part of the brain marked in the picture is the motor cortex (3) and it is responsible for the muscular movements. The part of the motor cortex that is close to the Broca's area is responsible for the articulatory muscles of the jaw, face, as well as tongue and larynx.

Part (4) in the picture shows arcuate fasciculus which is a bundle of nerve fibres connecting Wernicke's and Broca's areas.

Broca's area is the major surface of every human brain, which plays an important role in speaking and developing the speech process. Moreover, it is the most functional part of the brain.

According to Skipper, Goldin-Meadow, Nusbaum and Small's work [7, p. 260-277] Broca's area is responsible for: language comprehension; action recognition and production; speech-associated gestures. As a result, this part of the brain is very important. Each of the following postulates briefly shows the description of every Broca's area function.

Language comprehension. For a long time, it was assumed that the role of Broca's area was more devoted to language production than language comprehension. However, recent evidence demonstrates that Broca's area also plays a significant role in language comprehension. Skipper, GoldinMeadow, Nusbaum and Small prove that "patients with lesions in Broca's area who exhibit a grammatical speech production also show inability to use syntactic information to determine the meaning of sentences" [7, p. 271]. In other words, there is a close connection between language comprehension and production in every human brain, especially in Broca's area. A grammatical speech is not the only one result of problems.

Action recognition and production. Recent experiments have indicated that Broca's area is involved in various cognitive and perceptual tasks. One important contribution of this area is also found in the motor-related processes. The research of Fadiga and Craighero, based on "meaningful hand shadows resembling moving animals activates frontal language area", demonstrates that "Broca's area indeed plays a significant role in interpreting action of others" [3, p. 77-89]. Therefore, Broca's area is responsible for the correlative process of action recognition and production of speech. 
In the past many scientists tried to identify the connection between "the activity of particular brain parts and hearing a word, understanding, then finally producing it" [8, p. 140]. The leading neurologists, David Caplan, believed that it would follow the simple scheme [8, p. 140], "Speech is heard and comprehended via the Wernicke's area. Then the signal is transferred via the arcuate fasciculus to Broca's area where preparations are made to produce it. Finally, the signal is sent to the motor cortex to articulate the word" [8, p. 140]. Without a doubt, it is only the oversimplified scheme of what may actually take place. "There is some kind of metaphor of real construction and organization of the pathways in the human brain" [8, p. 140].

People are forced to use metaphors mainly because they cannot obtain direct physical evidence of linguistic processes in the brain. They have no direct access and generally have to rely on discoveries via indirect methods. Even world-famous scientist Sigmund Freud often used a steam engine metaphor to describe many aspects of the brain's activity.

There are several situations in every-day life when almost everyone has speech problems. It mainly happens when the brain tries to organise linguistic messages. A number of researchers have noted that many people experience occasional difficulty in getting brain and speech production to work together smoothly $[8$, p. 140]. The production of this sort of difficulties may provide possible clues to how our linguistics knowledge is organised within the brain.

There can be distinguished three main types of speech errors: (1) the tip of the tongue phenomenon; (2) slips of the tongue; (3) slips of the ear.

"The tip of the tongue (TOT) phenomenon refers to the experience of feeling confident that one knows an answer, but is unable to produce the word" [8, p. 143]. For example, in a conversation or writing most people have had the occasional experience of trying, but failing to retrieve someone's name or a word from memory.

New research suggests forgetfulness may have to do with how frequently we use certain words. The findings could help scientists understand more about how the brain organizes and remembers language.

"There are often strong phonological similarities between the target word and the mistake, which is produced instead. Research shows that many speakers generally have an accurate phonological outline of the word, can get the initial sound correct and mostly know the number of syllables in the missing word". This kind of mistake is called malapropism after Mrs Malaprop from Sheridan's play. One of the examples of this phenomenon is when a politician is alleged to have said that he would support a colleague to the best of his "mobility", instead of "ability" [2, p. 206]. Sometimes the tips of the tongue cause funny or even embarrassing situations. Archie Bunker suggested that "We need a few laughs to break up the monogamy" [2, p. 206].

The tips of the tongue are very common and happen almost with everyone. However, not many know that they directly come from the human brain. The aim is to remember that it is not a simple mistake but an error located in the speech centre.

Another type of common speech error is commonly described as a slip of the tongue. However, it has been suggested that it may result from the slip of the brain, especially the linguistic organization of messages in the language centre. George Yule believes that "slips are never random, they never produce a phonologically unacceptable sequence, and they indicate the existence of different stages in the articulation of linguistic expressions" [8, p. 141].

The slip of the tongue is described as an accidental and usually trivial mistake in speaking. It is sometimes called spoonerism after William Spooner, the clergyman at Oxford University. At the end of the 19th century, the Reverend William A. Spooner, Dean and Warden of New College, Oxford, earned a place in history when a new word based on his name was named spoonerism. He probably would have preferred a different reason for his fame than producing speech errors, unintentionally departing from what he meant to say. The following examples express the characteristic style of William Spooner $[4$, p. 3]:

- noble tons of soil for noble sons of toil;

- shoving leopard for loving shepherd;

- Let me sew you to your sheet_for Let me show you to your seat.

Most everyday slips of the tongue are not so funny. Everyone seems to produce such slips of the tongue. Sigmund Freud was aware of this fact and in 1901 based his monograph, Psychopathology of everyday life, on such errors claiming that "slips of the tongue resulted from repressed thoughts which are revealed by the particular errors which a speaker makes" [4, p. 2]. While it is possible that Freud is correct in some cases. such errors reveal as much if not much more about the structure of language as they do about repressed thoughts [4].

All common slips can be divided into six main groups [4, p. 2]:

(1) stick in the mud $>$ smuck in the tid (consonant segments exchange); 
(2) ad hoc > odd hack (vowel segments exchange);

(3) unanimity $>$ unamity (syllable deleted);

(4) easily enough $>$ easy enoughly (suffix moved);

(5) tend to turn out $>$ turn to tend out (words exchange);

(6) my sister went to the Grand Canyon > the grand canyon went to my sister (whole phrase exchange).

"Speech errors also show a great deal about the structure and organization of the mental dictionary, the storage house of all the words a speaker of a language knows" $[4$, p. 2]. It is very important in developing the knowledge about the complex structure of the human brain. Between typical speech errors common slip of the tongue is called misunderstanding. There are a couple types of slips. The most popular division and examples are taken from S. Garnes and Z. Bond [1, p. 235].

Slips of the ear:

1) substitutions:

- death in Venice - deaf in Venice;

2) syntactic accommodation:

- It'll be done next year - It'll be done in six years;

3) deletions:

- He got ten years in prison - He got tenure in prison;

4) additions:

- Chomsky was the most literate - Chomsky was the most illiterate;

5) word boundary deletions:

- coke and a Danish - coconut Danish;

6) word boundary insertions:

- ketchup - a chip;

7) word boundary shifts:

- new dimensions - nude mentions;

8) metathesis:

- some sealing tape - some ceiling paint;

9) complex misperceptions:

- I seem to be thirsty - I sing through my green Thursday;

10) anticipation:

- the mythology course is the pull course in Classics - the cool course;

11) perseveration:

- you are a butterfly - you are a fudge pie;

- there's a bad moon on the rise - there's a bathroom on the right;

- I'll never be your beast of burden - I'll never be your pizza burning;

- I'm going to brush my teeth - I'm going to flash my teeth;

- Do we have any bay leaves? - Do we have any Bailey's?
12) child misperceptions:

- Mother: Natives of New Guinea go out lumbering every day.

Child: What's tumbering, Mommy?

Tots may be nonsensical, although they follow grammatical rules. It is sometimes funny, but all of them are also syntactically appropriate. However, children can sometimes misperceive phonologically inappropriate words. The common example of that phenomenon comes from a religious song "Gladly the cross I'd bear" which was very often mispronounced by children in Sunday school. They were singing the song about the bear called "Gladly" who was cross-eyed [8, p. 144].

Some of these humorous examples give a clue how the normal working human brain copes with language. Although, many problems with language production and comprehension are the result of more serious disorders in the brain function.

The phenomenon of aphasia is described as "a disorder that results from damage to portions of the brain that are responsible for language".

The basic classification of different types of aphasia: Broca's aphasia; Wernicke's aphasia; Conduction aphasia. The following division depends on the localization of the brain damage in particular brain parts in the language centre.

Broca's aphasia is a serious speech disorder known also as motor aphasia. People suffering from motor aphasia have a substantially reduced amount of speech, distorted articulation and slow, effortful words production. Aphasic speech is called agrammatic because of functional morphemes omission like articles and prepositions.

The present article provided insight into the relationship between language and the brain. There is no doubt that particular brain parts are responsible for many speech mistakes, misunderstandings and handicaps. The language centre located in the left hemisphere has a huge impact on the language abilities of every human being. The phenomenon of the brain structure is the basis for neurolinguistics research.

Conclusions. The latest findings reflect the language-brain relationship as well as the corresponding hypotheses about the neural representation and processing in terms of spoken / printed word forms, word meanings, and sentences. Advanced developments in the field of neurolinguistics enable fruitful multidisciplinary collaboration of researchers with different backgrounds referring to applied linguistics, psychology, computer science, etc. the results of which can be incorporated into the curriculum of the related ESP courses. 
References:

1. Bond Z., Garnes S. A slip of the ear: a snip of the ear? A slip of the year? Errors in linguistic performances / Ed. by V. Fromkin. New York : Academic Press, 2000. P. 231-239.

2. Brown A. S. A review of the tip of-the-tongue experience. Psychological Bulletin. 1991. Vol. 109. № 2. P. 204-223.

3. Language in Shadow / L. Fadiga et al. Social Neuroscience. 2006. Vol. 1. Iss. 2. P. 77-89. DOI: $10.1080 / 17470910600976430$.

4. Fromkin V. A. Slips of the Tongue: Windows to the Mind. Los Angeles : The University of California, Linguistic Society of America, 2003. 3 p.

5. Ingram J. C. L. Neurolinguistics: An Introduction to Spoken Language Processing and its Disorders. Cambridge University Press, 2007. 444 p. URL: https://dl.uswr.ac.ir/bitstream/Hannan/140198/1/9780521791908. pdf.

6. Kemmerer David. Neurolinguistics: Mind, brain, and language. The Routledge Handbook of Linguistics / Keith Allan (Ed.). New York: Routledge, 2014. URL: https://www.researchgate.net/ publication/262284156_Neurolinguistics_Mind_brain_and_language.

7. Speech-Associated Gestures, Broca's Area, and the Human Mirror System / J. I. Skipper. Brain and Language. 2007. Vol. 101. Iss. 3. P. 260-277. DOI: 10.1016/j.bandl.2007.02.008.

8. Yule G. The Study of Language. $4^{\text {th }}$ edition. New York : CUP, 2010. 307 p.

\section{Байбакова І. М., Гасько О. Л. ТЕОРЕТИЧНІ ТА ЕМПІРИЧНІ ПИТАННЯ НЕЙРОЛІНГВІСТИКИ В КОНТЕКСТІ ВИВЧЕННЯ АНГЛІЙСЬКОЇ МОВИ ФАХОВОГО СПРЯМУВАННЯ}

Стаття присвячена аналізу теоретичних та емпіричних досліджень у галузі нейролінгвістики, яка останнім часом зазнала бурхливого розвитку завдяки поєднанню наукових досягнень сучасної лінгвістики, новому погляду на нейровізуалізацію, зокрема вдосконаленню численних методів картування мозку, швидкому поступу комп 'ютерних наук. Відзначаючись міждисциплінарним характером, результати иих досліджень можуть бути корисними для студентів спеціальностей медицини, філології, програмування, штучного інтелекту, машинного навчання тощо.

Нейролінгвістика вивчає механізм функиіонування розуму, мозку та мови і стосується широкого спектра питань щодо мовних ділянок мозку, аспектів мовної компетенції, обробки інформації в реальному часі, нейронних мереж, сприйняття мови, слухової обробки, проблеми розпізнавання мови, лексичної семантики, лексичної і синтаксичної багатозначності тощо. Результати та висновки сучасних досліджень відображають взаємозв'язок мови та мозку, а також підтверджують відповідні гіпотези щодо нейронного представлення й обробки з погляду вимовлених / друкованих форм слів, значень слів та речень.

Вивчення будови мозку є основою нейролінгвістичних досліджень. Мовний центр, розтамований у лівій півкулі, має величезний вплив на мовні здібності кожної людини. Взаємозв'язок мови та мозку проявляється й у процесі виникнення мовленнєвих помилок та непорозумінь.

Виділяють три основні типи мовних помилок, а саме: (1) явище «на кінчику язика»; (2) обмовки; (3) недочуте. Алгоритм їх розуміння може надати можливі підказки про те, яким чином наші мовні знання організовані в мозку, підвищити ефективність когнітивного прочесу загалом.

Передові міждисииплінарні дослідження у сфері нейролінгвістики дають змогу науковиям різних галузей науки плідно співпраџювати. Стаття зосереджена на аналізі останніх досягнень у галузі нейролінгвістики, засадничі аспекти яких можуть бути включені до програми курсів англійської мови фахового спрямування для спеціальностей напрямів прикладної лінгвістики, психології, комп 'ютерних наук тощзо.

Ключові слова: нейролінгвістика, міждисциплінарна галузь досліджень, взаємозв'язок «мова мозок», навчальна програма, курси англійської мови фахового спрямування. 